\title{
HHDoes Use of ICT-Based Teaching Encourage Innovative Interactions in the Classroom? Presentation of the CLI-O: Class Learning Interactions - Observation Tool
}

\author{
Edith Manny-lkan, Tal Berger Tikochinski, and Zipi Bashan \\ Henrietta Szold Institute, Jerusalem, Israel
}

edithmi@szold.org.il; tal@szold.org.il; zipi@szold.org.il

\begin{abstract}
This article presents a new classroom observations analysis tool (CLI-O: Class Learning Interactions - Observation tool). The CLI-O tool enables the collection of various data regarding the use of ICT tools, organization of learning, and teacher-student interactions in the lesson. Several examples demonstrating the use of CLI-O and some preliminary findings derived from this tool are presented. CLI-O was developed in order to answer the question: Is learning in an ICT-based environment characterized by a unique pedagogy expressed, for example, by student-centered pedagogy while the teacher serves as a guide who mediates learning using a variety of technological tools? For example, in lessons observed and analyzed by CLI-O in the present study, a large part of the learning was found to be whole class learning, mainly frontal learning, and the teacher was at the focus of the lesson. CLI-O supplies a systematic description of classroom processes and enables teachers, teacher educators, and researchers to examine the implementation of ICT in teaching and learning and perceive it as a gradual ongoing process of building a new pedagogy tailored to the needs of the $21^{\text {st }}$ century.
\end{abstract}

Keywords: Interactive learning, class observation, ICT-based teaching

\section{Introduction}

A learning environment that incorporates ICT (Information and Communications Technology) may afford possibilities for interactive learning, in which the students are active, receive feedback (from the teacher and/or from the ICT tools), and thus improve their understanding and construct

Material published as part of this publication, either on-line or in print, is copyrighted by the Informing Science Institute. Permission to make digital or paper copy of part or all of these works for personal or classroom use is granted without fee provided that the copies are not made or distributed for profit or commercial advantage AND that copies 1) bear this notice in full and 2) give the full citation on the first page. It is permissible to abstract these works so long as credit is given. To copy in all other cases or to republish or to post on a server or to redistribute to lists requires specific permission and payment of a fee. Contact Publisher@InformingScience.org to request redistribution permission. new knowledge (Schwartz et al. as cited in Committee on Developments in the Science of Learning, 2000). Studies performed in ICT-based environments demonstrated that the teacher can more easily serve as a guide, counselor, and coordinator (Tubin, Mioduser, Nachmias, \& Forkosh-Baruch, 2003; Zeira, 2002), such that it will lead to a relationship with the students which pro-

Editor: Janice Whatley

An earlier, shorter version of this paper was presented at the Chais conference 2013, in Raanana, Israel, and included in Y. Eshet-Alkalai, A. Caspi, S. Eden, N. Geri, Y. Yair, \& Y. Kalman (Eds.), Proceedings of the Chais Conference for Innovation in Learning Technologies 2013: Learning in the Technological Era. Raanana: The Open University of Israel. http://www.openu.ac.il/innovation/chais2013 
motes familiarity and collaboration rather than authoritativeness (Burns \& Polman, 2006; Freire, 1981). Thus, the conduct of a class in which ICT-based learning takes place is expected, at least potentially, to differ from that taking place in a "traditional" classroom where the teacher is the exclusive authority. Utilization of the potential inherent in ICT tools for improving teachinglearning processes may lead to a student-centered learning interaction, under guidance of the teacher. Nonetheless, it was found that in practice, use of interactive ICT tools in the lesson do not necessarily ensure such an innovative pedagogical interaction in the classroom (Hennessy, Deaney, Ruthven, \& Winterbottom, 2007).

\section{Literature Review}

The pedagogical interactions in the classroom can be classified in several ways, such as interactions between the learners and the ICT tool, between the teacher and the learners, and among the learners (Blau, 2011). The present article focuses on interactions between the teacher and the learners, with emphasis on the dimension of control afforded to the students during the course of the lesson (Tanner, Jones, Kennewell \& Beauchamp, 2005). This is an interaction spectrum that ranges from the "lecture" approach where the teacher has a high level of control over the contents and course of the lesson, through the encouragement of asking inquiry questions for raising different viewpoints among the students, and ending with a teaching situation in which the students and the teacher make an equal contribution to the construction of the lesson's contents and structure (Alexander, 2004; Beauchamp \& Kennewell, 2010).

The nature of the pedagogical interaction that takes place in the classroom may be dependent, to a great extent, on the professional development of the teacher and on his or her prior experience in incorporation of ICT in teaching. In this context, the research literature presents different developmental models that describe teachers' ongoing dealing with ICT-based teaching. For example, the model presented by Rogers (2003) views the incorporation of ICT in education as an ongoing process of pedagogical innovation, in which different levels of innovation may be demonstrated. He divides the change that is created in the school as a result of the implementation of ICT into three major categories (Forkosh-Baruch, Mioduser, \& Nachmias, 2012)

Continuous innovation: Improvement of existing pedagogical aspects using the new ICT tools similarly to previous uses. The change is at a relatively low level and the action is within the boundaries of the existing framework.

1. Dynamically continuous innovation: There are innovative processes which indicate a meaningful change in the teaching and learning processes in some of the fields in the school.

2. Discontinuous innovation: There are innovative and unfamiliar products, which indicate a change in all fields of the existing system.

Additional models deal with the development of teaching as a result of the incorporation of an interactive whiteboard in the classroom, but we feel that they can be viewed as general models for the implementation of an innovative ICT tool in the classroom.

Betcher and Lee (2009) call the process of the implementation of the interactive whiteboard "a quiet revolution" and divide it into three stages:

1. In the first stage, "doing old things in old ways", teachers teach the same contents using traditional methods.

2. In the second stage, "doing old things but in new ways", teachers introduce some changes, but the teaching methods do not undergo a significant change.

3. In the third change, "doing new things in new ways", innovative pedagogies are implemented. 
Another model was proposed by Burden (2002). This model presents a three-stage typology for using the interactive whiteboard:

1. In the first stage, "infusion", the ICT tools reinforce the existing pedagogy, and the students are mainly passive.

2. In the second stage, "integration", there is the beginning of a change in the existing pedagogy and an attempt is made to turn the students into active learners.

3. In the third stage, "transformation", ICT is used in order to afford an added value to the learning process. The teachers use diverse learning resources whose purpose is to expand an inquiry-based process. The students are involved in the use of ICT, with collaborative construction of knowledge in the course of interaction between the teacher, the students and the ICT tools.

It is interesting to note that what is in common to the three above-presented models is the developmental process which they describe. Although each model chooses different concepts to describe the process, they all refer to three similar stages, which move on a spectrum from teaching that is reminiscent of traditional teaching to teaching that has innovative pedagogical characteristics.

These models raise several questions: How can we tell the stage (of the different stages presented in the literature) at which the teachers, who are the agents of change, are found in related to the implementation of ICT? Is their teaching more traditional and frontal or more innovative and interactive or perhaps it is a combination of both? In order to answer these questions, it is necessary to actually enter the classroom during the lesson and analytically and systematically observe the interactions that take place between the teacher and the students during a lesson that incorporates different ICT tools. Such a systematic observation enables the identification and characterization of the pedagogy that takes place in ICT-based lessons. The data base that is obtained from the observation of a large variety of lessons will serve teachers, researchers, and policy makers as a basis for an in-depth understanding of the pedagogical interaction which is created in ICT-based learning environments and can serve as the basis for making decisions. For example, which ICT tools to acquire, for which age group, in which subjects should they be incorporated, where they should be installed - in the classrooms or in laboratories, etc.?

\section{The Rationale for the Development of CLI-O}

Research tools that enable a systematic observation of interactions that take place in the classroom have been reported in the research literature. For example, the CLASSTM tool (http://www.teachstone.org/about-the-class/) which enables the documentation of dimensions such as the class climate, the teacher's attitude towards the students' positions, class management, and the nature of the feedback given to the students by the teacher. The CLASSTM tool does not take into account the uniqueness of teaching and learning in an ICT environment. This environment can potentially promote student-centered learning by using various technological devices that enable individual and collaborative learning (Hsu, 2011; Smeets \& Mooij, 2001). Therefore there is a need for specific evaluation tools that capture these elements in the classroom. An example for such a tool is the indicator which Blau (2012) developed for assessing teacher's professional development in preparation for incorporating interactive whiteboards in schools. However, this tool was designed for evaluating the use of a single technological device and is inadequate when there are various devices being used. This article will present the Class Learning Interactions - Observation tool (CLI-O) which is a framework for evaluating and measuring learning organization and interactions in an ICT environment using various technological devices. The paper demonstrates the use of the tool and some preliminary findings that can be produced from using CLI-O. 


\section{The Research Tool}

The Class Learning Interactions - Observation tool (CLI-O) was constructed in order to enable systematic observation of the components of ICT-based lessons in different dimensions: The structure of the lesson (i.e., the organization of learning in the lesson) and the nature of interactions taking place between students and their teachers in an interactive ICT environment (see an example of the tool in Appendix A). These dimensions can contribute to the establishment of an innovative pedagogy, for example, by creating an environment which promotes $21^{\text {st }}$ century skills such as student-centered autonomic and collaborative learning.

These dimensions are measured in the CLI-O tool as following:

A. Percentage of using ICT in an ICT-based learning environment: The percentage of using ICT was measured by measuring the times during which the teacher employs various technological tools (interactive whiteboard and/or laptops) during the course of the lesson.

B. Organization of learning in an ICT-based learning environment: The organization of learning was characterized by measuring the times during each observation in which the class worked as a whole, in groups/pairs or individually. The time it took to organize learning was also calculated. This included for example the time it took the students to set up the technological tools (such as the laptops) for learning. This measurement was done in order to assess the amount of time "wasted" during the lesson due to the use of technology.

C. Nature of the interaction in an ICT-based learning environment: In order to understand the nature of the interaction between the teachers and the students in ICT-based lessons, the interactive components of the lesson were measured in each lesson, as follows (based on Beauchamp \& Kennewell, 2010):

1. No interaction between the teacher and the students: The entire content of the lesson is given by the teacher, who lectures and illustrates the learning material. The students usually view or read the text which the teacher presents using ICT tools and are not actively involved.

2. Teacher-centered interaction: The entire structure of the lesson and most of its content are determined by the teacher. The students are asked questions that have a clear answer (such as an answer to an exercise in mathematics) and the interaction is therefore limited. The teacher uses this kind of interaction in order to teach facts and skills.

3. Combined teacher and student-centered interaction: The entire structure of the lesson is determined by the teacher, but not all the contents. The teacher can initiate a discussion and take the students' answers into account as well. However, the goal of the discussion will be to encourage the students to adopt the conventional viewpoint pertaining to a particular issue/concept/content. The teacher's goal in this type of interaction is to develop knowledge pertaining to concepts and processes.

4. Student-centered interaction: The teacher and the students jointly contribute to the structure and content of the lesson. The purpose of the discussions in the lesson is to create diverse points of view, through in-depth understanding of concepts and processes. The teacher usually responds to the students' sayings in a reflexive manner, with the aim of applying concepts and processes to different and diverse situations. 


\section{How CLI-O is Used}

An observer from the research team is trained to write a detailed description of a lesson he is observing on the CLI-O form (see Appendix A). The observer describes in detail each different activity which takes place in the lesson (with and without technology). The observer also documents the duration (in minutes) of each activity. The CLI-O form is then analyzed and for each lesson there is a measure of the percentage of time in which a) technology was used, b) different models of learning organization were practiced, and c) different models of interactions were created by the teacher (see Appendix B, Table 1). For example if the teacher gives an explanation to the class in a lecture form and the students are not actively involved then this activity will be scored as "no interaction". If the teacher asks the students to answer closed questions with one correct answer determined by the teacher, then this activity will be scored as "teacher centered". As opposed to that, if the students contribute to the lesson by preparing a small learning unit which they teach their peers, then this activity will be scored as "student centered" (see detailed examples in Appendix A).

Described below is an example of the use of CLI-O in an evaluation research.

\section{Methodology}

\section{The Research Sample}

The findings presented in the current paper summarize 21 systematic observations that were carried out in classes in which ICT-based learning takes place by means of interactive whiteboards and laptops, during the 2011-2012 and the 2012-2013 school years. The observations were made in an elementary school in which ICT-based learning has been taking place for about five years. This is a science-oriented elementary school that is located in a small urban city in the south of the country. All parent classrooms in this school are equipped with an interactive whiteboard, and there are 90 laptops which serve the entire student population in the school. The teachers in whose classes the observations were made $(n=3)$ are skilled in use of the interactive whiteboard and the observations were made during the first and second years in which laptops were incorporated for teaching. Each teacher was followed for two years. It should be indicated that, in this school, ICT comprises an integral part of the school's organizational culture and includes entry of attendance in the classes, sending electronic messages to the parents, and email communication between the school administration and the teachers.

\section{Data Analysis}

During the observation, the observer documented the course of the lesson in writing. The lesson was divided into time units for data processing, according to its various characteristics: those pertaining to the percentage of time in which technology was used in the lesson, those related to the organization of learning in the lesson, and those pertaining to the nature of the interaction between the teacher and the students (see examples in Appendix A). These times were calculated separately for each of the analysis categories, in each of the observed lessons. The median that summarizes all observations data from all the lessons was then calculated for each of the characteristics (see Appendix B, Table 1). The median was used in order to summarize the findings because this index is less sensitive to outliers (compared to the mean) and it was more appropriate since the sample size was relatively small and heterogeneous.

The raw data from the observations were given to two researchers who are experts in ICT-based learning for analysis, in order to ensure agreement on the classification of the lesson contents into its different characteristics. A joint discussion was held after a preliminary analysis by each re- 
searcher separately, until they reached $100 \%$ agreement on the interpretation of the data in each of the above-mentioned characteristics.

\section{Findings}

Select findings that illustrate use of the CLI-O tool will be presented henceforth. An example of findings on the percentage of use of ICT during the lessons will be presented first:

\section{Use of ICT}

Observations made in nine lessons during the first year of using laptops (2011-2012) showed a median ICT use of up to $60 \%$ of the lesson time. It should be indicated that prolonged use of the CLI-O in these classes showed that after several years, the distinction in the duration of ICT use during the lesson diminished, and after four years, the teachers became more skilled in ICT-based learning environments and used the ICT tools for different needs during the entire lesson, such that documentation of a distinction between the time devoted to use of ICT and time in which learning without ICT takes place became less relevant.

An example that refers to the measurement of the median percentage of the lesson time devoted to organization of learning in lessons which take place in an ICT-based environment between 2011 and 2013 is presented below.

\section{Organization of learning}

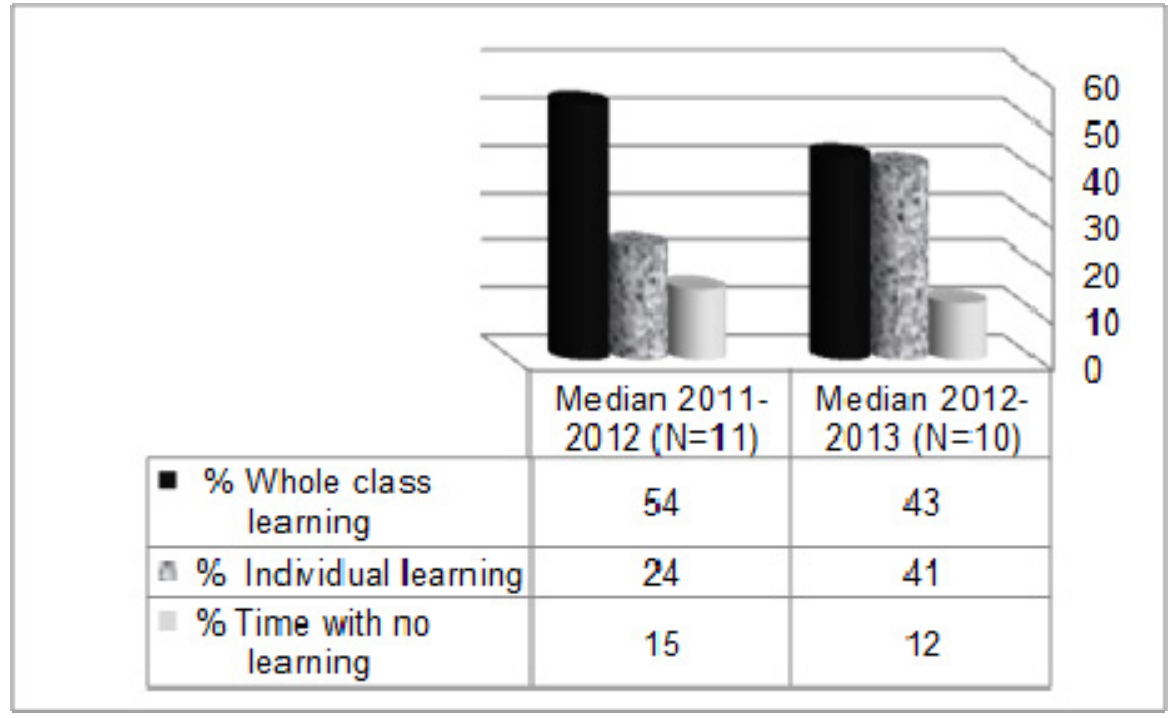

Figure 1: Organization of learning in ICT-based lessons

Figure 1 demonstrates that organization of learning during the 2011-2012 school year in the 11 lessons which were observed is mainly traditional: the median of whole class learning was $54 \%$ of the lesson time, and the median of individual learning was $24 \%$ of the lesson time. It can further be seen that up to $15 \%$ of the lesson time in half of the lessons is devoted to the organization of learning (taking laptops out and turning them on, etc., time during which learning does not actually occur). During the 2012-2013 school year, whole class learning time decreased, since in half of the lessons it occupied up to $43 \%$ of the time, and individual learning time increased (up to $41 \%$ of the lesson time in half of the lessons) and the time devoted to the organization of learning decreased. 
Another example of CLI-O use refers to measurement of the median percentage of the lesson time devoted to learning interactions that take place in ICT-based lessons. Findings in this aspect in the 2011-2013 school years are presented below.

\section{Learning interactions in ICT-based lessons}

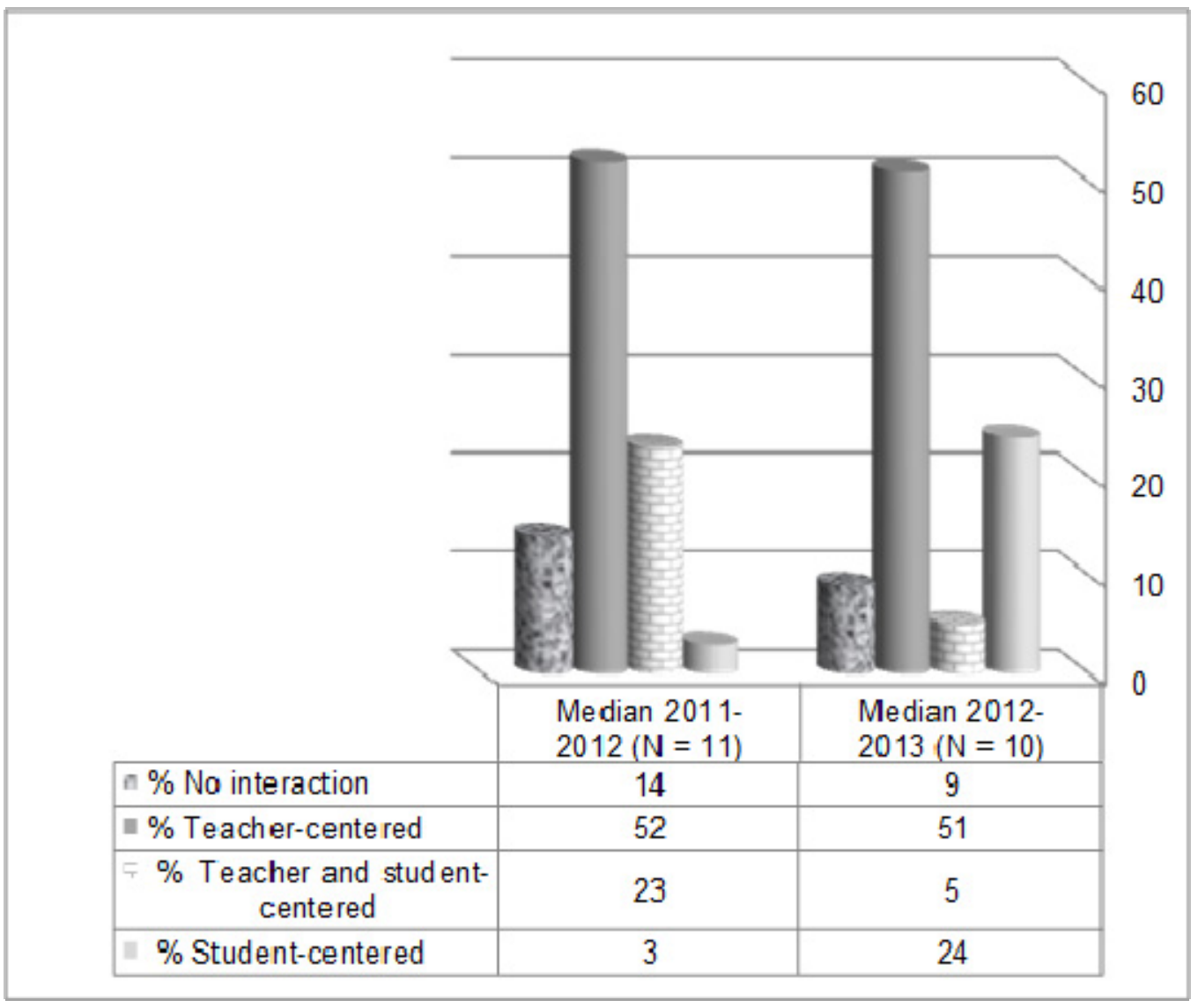

Figure 2: learning interactions between the teacher and the students in ICT-based lessons

Figure 2 demonstrates that during the 2011-2012 school year, in half of the lessons, 52\% of the lesson time was with a teacher-centered interaction and $14 \%$ was with no interaction. Furthermore, up to one quarter of the lesson time $(23 \%)$ was with a combined teacher and studentcentered interaction. During the 2012-2013 school year there was greater emphasis on studentcentered learning (median of 24\%) and a decrease in learning with no interaction (median of 9\%).

\section{Summary of the Findings and Discussion}

Use of the CLI-O tool enables the collection of various data on the use of ICT tools in the lesson, organization of learning, and teacher-student interactions. In the school observed in the present study, a large part of the learning (in the 2011-2012 school year) was whole class learning, mainly frontal learning, and the teacher was at the focus of the lesson. The structure of the lesson and most of its contents were determined by the teacher. The interaction between the teacher and the students was limited and in most of the lessons there was little room for the students' contribution. Analysis of the observations using the CLI-O tool demonstrates the "technological paradox", which refers to teachers who use innovative ICT tools but implement them using traditional pedagogy (Forkosh-Baruch et al., 2012). It should be indicated that the findings were submitted 
to the school principal after the 2011-2012 school year, and she decided that her pedagogical goals for the 2012-2013 school year were to promote individual learning using laptops. She therefore instructed the teaching staff to prepare lessons that include components of individual learning as well as group and collaborative tasks. These tasks focused on students' interests and included individual research projects and group presentations. The findings indicate that these trends were indeed expressed in the lessons of the teachers whom we observed. Greater emphasis was given to student-centered learning and less to teacher-centered learning and the organization of learning demonstrated an increase in the frequency of individual learning. The school also acquired skills in operating ICT tools, such that a greater percentage of the lesson time was utilized for learning.

Nonetheless, with reference to the different developmental models mentioned above, it seems that in most cases the teachers, even in the second year of the study, are found between the first and the second stage, as detailed in the models. Some carry out traditional actions using innovative means and some attempt to turn the students into active learners, as demonstrated by the CLI-O tool. It can be assumed that continued use of laptops in the lessons may promote aspects related to the impartation of skills necessary for the $21^{\text {st }}$ century, such as: collaborative learning (Marsh, Taylor, \& Holoviak, 2008) and the promotion of an autonomous learner (David, 2007; Kleiger, Ben-Hur, \& Bar-Yosef, 2008; Levin \& Wadmany, 2006; Manny-Ikan, Berger-Tikochinski, Beeri, \& Efrati, 2011; Rockman, 2006).

\section{Conclusion and Future Work}

The findings obtained via the CLI-O tool indicate the different interactions that take place between the teacher and the students in ICT-based learning environments and their change over time. Use of CLI-O in conjunction with theory enables teachers, teacher educators, and researchers to implement ICT in teaching as a process of building a new pedagogy tailored to the needs of the $21^{\text {st }}$ century. Therefore CLI-O can also be used as a training tool for teachers starting to teach in an ICT environment on their way of becoming a $21^{\text {st }}$ century teacher.

There is a need for future research using CLI-O in larger samples of classrooms using ICT alongside traditional classrooms not using ICT. Further research could contribute to deeper understanding of the learning organization and interactions taking place at different settings of ICT learning environments (e.g., different age groups and subject matters). These findings could be compared to the learning organization and interactions taking place in traditional classrooms in order to define the contribution of ICT to learning in these aspects.

\section{References}

Alexander, R. J. (2004). Towards dialogic teaching: Rethinking classroom talk. Cambridge, UK: Dialogos.

Beauchamp, G., \& Kennewell, S. (2010). Interactivity in the classroom and its impact on learning. Computers \& Education, 54(3), 759-766.

Betcher, C., \& Lee, M. (2009). The interactive whiteboard revolution. Victoria, Australia: ACER Press.

Blau, I. (2011). Being a smart teacher in a "smart classroom": Assessing teacher professional development for incorporating interactive whiteboards at schools. In Y. Eshet-Alkalai, A. Caspi, \& S. Eden (Eds.), Proceedings of the 6th Annual Chais Conference on Instructional Technologies Research: Learning in the Technological Era (pp. 63-74). Ra'anana, Israel: The Open University of Israel. (in Hebrew)

Blau, I. (2012). The silent revolution: Promoting 21 th century pedagogy by implementing interactive whiteboards in education system. Journal of Theory and Research Ma'of u Ma'ase: Teaching and Learning in the Internet Era, 14, 139-156. (in Hebrew)

Burden, K. (2002). Learning from the bottom up - The contribution of school based practice and research in the effective use of interactive whiteboards for the FE/HE sector. Discussion paper presented at 
LSDA, Making an Impact Regionally Conference Doncaster, UK. Retrieved from http://www.lsnlearning.org.uk

Burns, K., \& Polman, J. (2006). The impact of ubiquitous computing in the internet age: How middle school teachers integrated wireless laptops in the initial stages of implementation. Journal of Technology and Teacher Education, 14(2), 363-385.

Committee on Developments in the Science of Learning. (2000). How people learn: Brain, mind, experience, and school. Washington, DC: National Academy Press. Retrieved October 23, 2013, from http://www.nap.edu/catalog/9853.html

David, Y. (2007). Learning and social processes in a laptop class; Motivation and academic achievement. A case study. Ramat-Gan, Israel: Bar-Ilan University, School of Education. (in Hebrew)

Forkosh-Baruch, A., Mioduser, D., \& Nachmias, R. (2012). ICT innovation in the international research. Journal of Theory and Research Ma'of $u$ Ma'ase: Teaching and Learning in the Internet Era, 14, 4922. (in Hebrew)

Freire, P. (1981). Pedagogy of the oppressed. Tel-Aviv, Israel: Mifras. (in Hebrew)

Hennessy, S., Deaney, R., Ruthven, K., \& Winterbottom, M. (2007). Pedagogical strategies for using the interactive whiteboard to foster learner participation in school science. Learning, Media and Technology, 32(3), 283-301.

Hsu, S. (2011). Who assigns the most ICT activities? Examining the relationship between teacher and student usage. Computers \& Education, 56(3), 847-855.

Klieger, A., Ben-Hur, Y., \& Bar-Yossef, N. (2008). What facilitates integration of one-to-one laptops according to science teachers? In Y. Eshet-Alkalai, A. Caspi, \& N. Geri (Eds.), Proceedings of the 3rd Annual Chais Conference on Instructional Technologies Research: Learning in the Technological Era. Ra'anana, Israel: The Open University of Israel. (in Hebrew)

Levin, T., \& Wadmany, R. (2006). Listening to students and teachers voices on learning with information technologies in a rich technology-based classroom. Proceedings of the first Annual Chais Conference on Instructional Technologies Research: Learning in the Technological Era. Ra'anana, Israel: The Open University of Israel. (in Hebrew)

Manny-Ikan, E., Berger-Tikochinski, T., Beeri, R., \& Efrati, R. (2011). Student achievements and attitudes towards learning in the "Time to Know" program. In Y. Eshet-Alkalai, A. Caspi, \& S. Eden (Eds.), Proceedings of the 6th Annual Chais Conference on Instructional Technologies Research: Learning in the Technological Era (pp. 267-268). Ra'anana, Israel: The Open University of Israel. (in Hebrew)

Marsh, M., Taylor, R., \& Holoviak, S. (2008). Enhancing classroom performance: A technology design to support the integration of collaborative learning and participative teams. College Teaching Methods \& Styles Journal, 4(6), 31-40.

Rockman, S. (2006). A more complex picture: Laptop use and impact in the context of changing home and school access. San Francisco.

Rogers, E.M. (2003). Diffusion of innovations (5th edition). NY: Free Press.

Smeets, E., \& Mooij, T. (2001). Pupil-centered learning, ICT, and teacher behavior: Observations in educational practice. British Journal of Educational Technology, 32(4), 403-417.

Tanner, H., Jones, S., Kennewell, S., \& Beauchamp, G. (2005). Interactive whiteboards and pedagogies of whole class teaching. Proceedings of the 28th Annual Conference of the Mathematics Education Research Group of Australasia, Melbourne. Sydney: MERGA

Tubin, D., Mioduser, D., Nachmias, R., \& Forkosh-Baruch, A. (2003). Educational innovation in ICT integrated schools in Israel. Israel: Tel Aviv University, School of Education. (in Hebrew)

Zeira, O. (2002). Development, implementation and evaluation of microcomputer based lab in immunology. Ramat-Gan, Israel: Bar-Ilan University, School of Education. (in Hebrew) 


\section{Appendix A: Examples of Using the CLI-O Tool}

Observation No.

Teacher's name:

Date:

Subject:

Number of students:

Grade:

Beginning of the lesson at time:

End of the lesson at time:

Instructions for the observer:

1. All the activities taking place in the classroom should be documented in detail.

2. Transition between activities (i.e., transferring to a new line in the table) will be made in the following cases: change in the nature of the organization of learning, change in the interaction, and change in the nature of learning with/without ICT.

3. Please make sure to document the times of the beginning and end of the lesson.

\begin{tabular}{|c|c|c|c|c|c|c|}
\hline $\begin{array}{l}\text { Activities } \\
\text { in the } \\
\text { lesson }\end{array}$ & $\begin{array}{l}\text { Activity } \\
\text { with } \\
\text { ICT } \\
\text { (time in } \\
\text { minutes }\end{array}$ & $\begin{array}{c}\text { Activity } \\
\text { without } \\
\text { ICT } \\
\text { (time in } \\
\text { minutes) }\end{array}$ & $\begin{array}{c}\text { Organization } \\
\text { of the learn- } \\
\text { ing (whole } \\
\text { class, group, } \\
\text { individual) }\end{array}$ & $\begin{array}{c}\text { Description of the activities of the teacher and the } \\
\text { students }\end{array}$ & $\begin{array}{c}\text { Activities carried } \\
\text { out using ICT and } \\
\text { using tools ... } \\
\text { what ICT tools } \\
\text { are being used? } \\
\text { What activity is } \\
\text { being performed? }\end{array}$ & $\begin{array}{l}\text { Coding of } \\
\text { the interac- } \\
\text { tion (after } \\
\text { the observa- } \\
\text { tion) }\end{array}$ \\
\hline \multirow[t]{2}{*}{ Example 1} & $\begin{array}{l}5 \text { min- } \\
\text { utes }\end{array}$ & & Whole class & $\begin{array}{l}\text { Opening - teacher's explanation of fractions, with entry } \\
\text { into a learning site for illustration of the material }\end{array}$ & $\begin{array}{l}\text { Interactive white- } \\
\text { board, entry into } \\
\text { the learning site } \\
\text { and reading from a } \\
\text { presentation }\end{array}$ & No interaction \\
\hline & $\begin{array}{l}13 \text { min- } \\
\text { utes }\end{array}$ & & Whole class & $\begin{array}{l}\text { From a science lesson, } \mathbf{6}^{\text {th }} \text { grade: A student approaches } \\
\text { the teacher's computer and using the mouse completes } \\
\text { words in a section out of a store of words: "The heat } \\
\text { emitted from burning ... warms the water and they turn } \\
\text { into ..." } \\
\text { When pressing the wrong answer, the correct answer } \\
\text { appears. }\end{array}$ & $\begin{array}{l}\text { Use of an interac- } \\
\text { tive whiteboard }\end{array}$ & $\begin{array}{l}\text { Teacher- } \\
\text { centered }\end{array}$ \\
\hline
\end{tabular}




\begin{tabular}{|c|c|c|c|c|c|c|}
\hline $\begin{array}{l}\text { Activities } \\
\text { in the } \\
\text { lesson }\end{array}$ & $\begin{array}{l}\text { Activity } \\
\text { with } \\
\text { ICT } \\
\text { (time in } \\
\text { minutes }\end{array}$ & $\begin{array}{c}\text { Activity } \\
\text { without } \\
\text { ICT } \\
\text { (time in } \\
\text { minutes) }\end{array}$ & $\begin{array}{l}\text { Organization } \\
\text { of the learn- } \\
\text { ing (whole } \\
\text { class, group, } \\
\text { individual) }\end{array}$ & $\begin{array}{l}\text { Description of the activities of the teacher and the } \\
\text { students }\end{array}$ & $\begin{array}{c}\text { Activities carried } \\
\text { out using ICT and } \\
\text { using tools ... } \\
\text { what ICT tools } \\
\text { are being used? } \\
\text { What activity is } \\
\text { being performed? }\end{array}$ & $\begin{array}{c}\text { Coding of } \\
\text { the interac- } \\
\text { tion (after } \\
\text { the observa- } \\
\text { tion) }\end{array}$ \\
\hline & & 9 minutes & $\begin{array}{l}\text { Individual } \\
\text { work }\end{array}$ & $\begin{array}{l}\text { From a geography lesson, } \mathbf{8}^{\text {th }} \text { grade: A team of stu- } \\
\text { dents hand out work sheets which they prepared for the } \\
\text { class (a quiz on the quality of the environment, arranged } \\
\text { according to the alphabet, for a given statement). } \\
\text { The students from the work team pass between the rest } \\
\text { of the students and examine their answers and give clues } \\
\text { when the students have difficulties. Note: The work } \\
\text { sheets are based on a presentation which the team of } \\
\text { students prepared and presented to the class in the les- } \\
\text { son. }\end{array}$ & & $\begin{array}{l}\text { Student- } \\
\text { centered }\end{array}$ \\
\hline & $\begin{array}{l}3 \text { min- } \\
\text { utes }\end{array}$ & & Whole class & $\begin{array}{l}\text { From a geography lesson, } \mathbf{8}^{\text {th }} \text { grade: The teacher con- } \\
\text { tinues with explanations on the strata (of the earth) of } \\
\text { each of the parts, in collaboration with the students, and } \\
\text { presents examples. Concomitantly she asks whether the } \\
\text { students felt the earthquake and a conversation arises } \\
\text { among the students, and in this context she asks whether } \\
\text { the earthquake is an external or an internal process and } \\
\text { asks the students to explain what happens during an } \\
\text { earthquake. One of the students explains and the others } \\
\text { help him when he does not remember a concept (such as } \\
\text { tectonic plates). }\end{array}$ & & $\begin{array}{l}\text { Combined } \\
\text { teacher and } \\
\text { student- } \\
\text { centered }\end{array}$ \\
\hline
\end{tabular}




\begin{tabular}{|c|c|c|c|c|c|c|}
\hline $\begin{array}{l}\text { Activities } \\
\text { in the } \\
\text { lesson }\end{array}$ & $\begin{array}{l}\text { Activity } \\
\text { with } \\
\text { ICT } \\
\text { (time in } \\
\text { minutes }\end{array}$ & $\begin{array}{l}\text { Activity } \\
\text { without } \\
\text { ICT } \\
\text { (time in } \\
\text { minutes) }\end{array}$ & $\begin{array}{l}\text { Organization } \\
\text { of the learn- } \\
\text { ing (whole } \\
\text { class, group, } \\
\text { individual) }\end{array}$ & $\begin{array}{l}\text { Description of the activities of the teacher and the } \\
\text { students }\end{array}$ & $\begin{array}{c}\text { Activities carried } \\
\text { out using ICT and } \\
\text { using tools ... } \\
\text { what ICT tools } \\
\text { are being used? } \\
\text { What activity is } \\
\text { being performed? }\end{array}$ & $\begin{array}{c}\text { Coding of } \\
\text { the interac- } \\
\text { tion (after } \\
\text { the observa- } \\
\text { tion) }\end{array}$ \\
\hline & $\begin{array}{l}5 \text { min- } \\
\text { utes }\end{array}$ & & Group work & $\begin{array}{l}\text { From a geography lesson, } 9^{\text {th }} \text { grade: The students are } \\
\text { working with their personal computers. The class is di- } \\
\text { vided into groups of } 5 \text { students which are working on } \\
\text { collaborative software on the internet called Cortex. The } \\
\text { students in each group are asked to express their } \\
\text { opinions on a subject from the learning material and also } \\
\text { to comment on their peers' opinion. All the group mem- } \\
\text { bers can see all the comments and a collaborative } \\
\text { document is created. }\end{array}$ & $\begin{array}{l}\text { Use of personal } \\
\text { computers }\end{array}$ & $\begin{array}{l}\text { Student- } \\
\text { centered }\end{array}$ \\
\hline
\end{tabular}




\section{Appendix B}

Table 1: Examples of Summarized Analysis Using the CLI-O Tool

\begin{tabular}{c|c|c|c|c|}
\cline { 2 - 4 } & \multicolumn{4}{|c|}{ Learning interactions in ICT-based lessons } \\
\cline { 2 - 5 } $\begin{array}{c}\text { Lesson } \\
\text { number }\end{array}$ & $\begin{array}{c}\text { \% Student } \\
\text { Centered }\end{array}$ & $\begin{array}{c}\text { \% Teacher } \\
\text { and Student } \\
\text { Centered }\end{array}$ & $\begin{array}{c}\text { \% Teacher } \\
\text { Centered }\end{array}$ & $\begin{array}{c}\text { \% No In- } \\
\text { teraction }\end{array}$ \\
\cline { 2 - 5 } 1 & $55 \%$ & $0 \%$ & $13 \%$ & $32 \%$ \\
2 & $43 \%$ & $0 \%$ & $51 \%$ & $6 \%$ \\
3 & $0 \%$ & $28 \%$ & $61 \%$ & $11 \%$ \\
4 & $0 \%$ & $0 \%$ & $100 \%$ & $0 \%$ \\
5 & $15 \%$ & $56 \%$ & $10 \%$ & $18 \%$ \\
6 & $68 \%$ & $18 \%$ & $0 \%$ & $15 \%$ \\
7 & $0 \%$ & $19 \%$ & $81 \%$ & $0 \%$ \\
8 & $0 \%$ & $9 \%$ & $88 \%$ & $3 \%$ \\
9 & $33 \%$ & $0 \%$ & $52 \%$ & $15 \%$ \\
10 & $80 \%$ & $0 \%$ & $12 \%$ & $7 \%$ \\
median & $24 \%$ & $5 \%$ & $51 \%$ & $9 \%$
\end{tabular}

\begin{tabular}{|c|c|c|c|}
\hline \multicolumn{3}{|c|}{ Organization of learning } \\
\hline $\begin{array}{c}\text { \% Whole } \\
\text { Class } \\
\text { Learning }\end{array}$ & $\begin{array}{c}\% \text { Group } \\
\text { Learning }\end{array}$ & $\begin{array}{c}\text { \% Indi- } \\
\text { vidual } \\
\text { Learning }\end{array}$ & $\begin{array}{c}\text { \% Time } \\
\text { With No } \\
\text { Learning }\end{array}$ \\
\hline $43 \%$ & $0 \%$ & $43 \%$ & $14 \%$ \\
$59 \%$ & $0 \%$ & $26 \%$ & $15 \%$ \\
$60 \%$ & $0 \%$ & $15 \%$ & $25 \%$ \\
$13 \%$ & $0 \%$ & $78 \%$ & $10 \%$ \\
$43 \%$ & $0 \%$ & $41 \%$ & $15 \%$ \\
$42 \%$ & $47 \%$ & $0 \%$ & $11 \%$ \\
$51 \%$ & $0 \%$ & $36 \%$ & $13 \%$ \\
$53 \%$ & $0 \%$ & $47 \%$ & $0 \%$ \\
$35 \%$ & $19 \%$ & $42 \%$ & $4 \%$ \\
$40 \%$ & $0 \%$ & $56 \%$ & $5 \%$ \\
$43 \%$ & $0 \%$ & $41 \%$ & $12 \%$ \\
& & & \\
\hline
\end{tabular}




\section{Biographies}

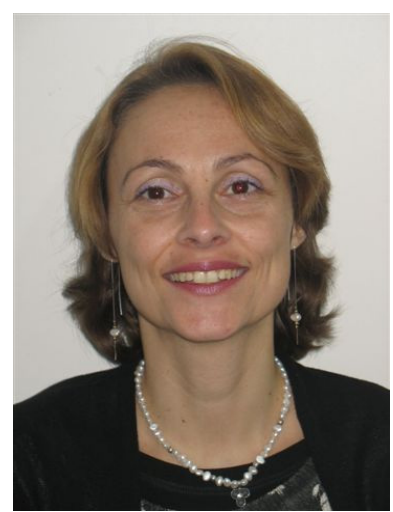

Dr. Edith Manny-Ikan is a senior researcher in the Henrietta Szold Institute - The National Institute for Research in the Behavioral Sciences in Israel. Her research interests focus on evaluating ICT programs and their effects on students' attitudes and achievements, teachers' perceptions about their changing professional role, schools change in ICT orientation and different effects of ICT on parents and the community. Dr. Manny-Ikan obtained her Ph.D. degree from the Faculty of Science Education at the Hebrew University of Jerusalem, Israel. She has written learning materials for high school and had also been a classroom teacher of Biology at elementary, middle and high school levels.

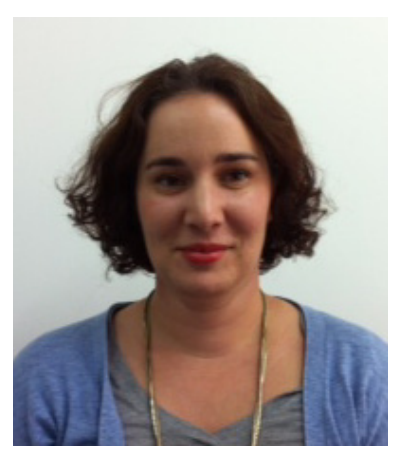

Tal Berger-Tikochinski is a researcher at the Henrietta Szold Institute - The National Institute for Research in the Behavioral Sciences in Israel. Her research interests include the use of ICT in education, from teachers' and students' perspectives. Mrs. Berger-Tikochinski is a second-year PhD candidate at the School of Education at Bar-Ilan University. She holds a B.A degree in Behavioral Sciences from Ben-Gurion University and an M.A degree in Sociology of Education from the Hebrew University of Jerusalem, Israel.

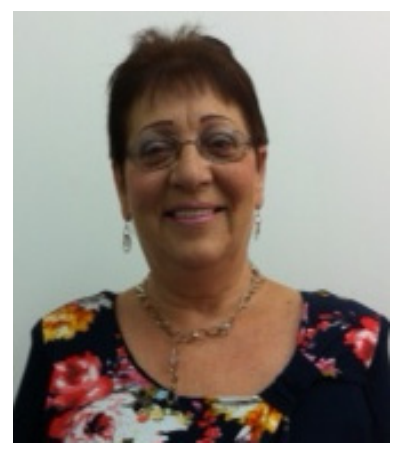

Zipi Bashan is a research assistant and a program coordinator in the Henrietta Szold Institute - The National Institute for Research in the Behavioral Sciences in Israel. Her research interests focus on evaluating ICT programs, assimilating various technologies in schools and she is an expert in using CLI-O. She has also developed and written learning materials for elementary schools. Mrs. Bashan has a B.A in Humanities and a teaching certificate from the Hebrew University of Jerusalem, Israel. 